Technological University Dublin ARROW@TU Dublin

\title{
Characterisation Of Cell Types In Abalone (Haliotis spp.) Tissues Using Immunohistochemical Techniques
}

\author{
Leanne Harris \\ Technological University Dublin, leanne.harris@tudublin.ie \\ Nuala O'Byrne-Ring \\ Technological University Dublin \\ Helen Lambkin \\ Technological University Dublin
}

Follow this and additional works at: https://arrow.tudublin.ie/scschbioart

Part of the Biology Commons

\section{Recommended Citation}

Harris, L., O'Byrne-Ring, N. and Lambkin, H. (2006) Characterisation of cell types in abalone (Haliotis spp.) tissues using immunohistochemical techniques. Aquaculture Vol. 261, Issue 4, 11 December 2006, Pages 1413-1421. doi:/10.1016/j.aquaculture.2006.09.021

This Article is brought to you for free and open access by the School of Biological Sciences at ARROW@TU Dublin. It has been accepted for inclusion in Articles by an authorized administrator of ARROW@TU Dublin. For more information, please contact arrow.admin@tudublin.ie, aisling.coyne@tudublin.ie,gerard.connolly@tudublin.ie. Funder: Technological University Dublin

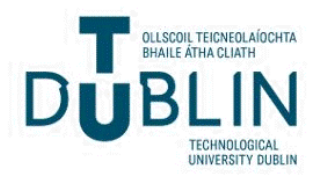




\title{
Characterisation of cell types in abalone (Haliotis spp.) tissues using immunohistochemical techniques
}

\author{
Leanne Harris, Helen Lambkin, Nuala O’Byrne-Ring* \\ School of Biological Sciences, Dublin Institute of Technology, Kevin Street, Dublin 8, Ireland \\ Received 26 July 2005; received in revised form 11 September 2006; accepted 15 September 2006
}

\section{Abstract}

The increasing popularity of abalone as a seafood delicacy has led to the rapid development of abalone aquaculture worldwide. The commercial and economic importance of this industry has resulted in an increasing interest in the biology of this particular shellfish genus. In this study we focus on the identification of structural, functional and proliferative proteins in two species of abalone shellfish, Haliotis discus hannai and Haliotis tuberculata. Monoclonal and polyclonal antibodies that react with proteins in vertebrate and invertebrate tissues were selected and applied to abalone tissues. Cross sections of whole animals were analysed using avidin-biotin immunoperoxidase staining protocols. In total, twenty-four antibodies were tested on shellfish tissues. Six antibodies out of twenty-four detected antigens in Haliotis spp. Cytokeratins, proliferating cell nuclear antigen $n_{\mathcal{N}}$ neuron specific enolase laminin and vimentin were detected in abalone tissues. Positive immunohistochemical results were confirmed using western blot. The expression of these proteins aids in the characterisation of cell types present in abalone tissues, which contributes to a better understanding of the fundamental biology of this shellfish genus.

(C) 2006 Published by Elsevier B.V.

Keywords: Abalone; Cell markers; Haliotis tuberculata; Haliotis discus hannai; Immunohistochemistry

\section{Introduction}

Abalone are marine gastropods consisting of 56 described species found in both temperate and tropical waters of both hemispheres (Bevelander, 1988; Geiger, 2000). Abalone aquaculture has become an economically important activity worldwide owing to a significant increase in consumer demand for this shellfish product. World cultured abalone production has soared phenomenally in recent times with over fifteen species currently in commercial cultivation (Gordon and Cook,

* Corresponding author. Tel.: +353 14024946; fax: +353 14024995 .

E-mail address: Nuala.OByrne.Ring@dit.ie (N. O’Byrne-Ring).
2004). Abalone shellfish are not native to Ireland but they were introduced in 1970. Land-based farms were set up along the Western seaboard for the commercial cultivation of two particular species of abalone, Haliotis tuberculata and Haliotis discus hannai. The histology of prosobranch and abalone shellfish has been studied (Bevelander, 1988; Voltzow, 1994) but there is a scarcity of information on the cellular and molecular constituents of shellfish in general.

Immunohistochemistry is a technique that demonstrates phenotypic antigen expression and was developed in the early 20th century. It allows for the demonstration of antigens in tissue sections by the use of specific immunological (antibody-antigen) interactions culminating in the attachment of a visible marker 
(usually an enzyme) to the antigen (Avrameas and Uriel, 1966; Nakane and Pierce, 1966). Cell markers are proteins characteristic of certain cell types. They may arise as surface cell markers that are molecules or proteins characteristic of the plasma membrane of a cell or as intracellular proteins that occur within the cell. Cell types and tissues express cell specific markers, which can be identified through immunohistochemistry (Miller, 2002).

The characterisation of cell types in higher vertebrates has been researched extensively but the information available for invertebrates remains scarce (Bacetti et al., 1984; Lyons-Alcantara et al., 1999). The human antibody repertoire can collectively target thousands of antigens but there is currently a limited range of antibodies that react with invertebrate antigens (Vullings et al., 1989; LyonsAlcantara et al., 1999, 2002; Panasophonkul et al., 2004). Owing to this factor immunohistochemical techniques have rarely been employed in the study of shellfish but there are a few studies that have utilised immunolocalisation methods. In marine research the use of monoclonal antibodies and immunohistochemical techniques has been concentrated in the study of marine immunology and infectious disease (Yoshino and Granath, 1983; Mialhe et al., 1988; Noël et al., 1994; Coll and Dominguez-Juncal, 1995; Roch, 1999; Xue and Renault, 2001). More recently immunohistochemical methods, using rabbit and mouse polyclonal antibodies, were employed to locate serotonergic and FMRF-amidergic neurons within the cerebral, pleuropedal and visceral ganglia of Haliotis asinina (Panasophonkul et al., 2004).

Immunohistochemistry has also been used in the study of cytokeratins in fish and invertebrates (Markl and Franke, 1988; Markl et al., 1989; Bunton, 1993; Diogo et al., 1994). Cells of the digestive gland of the Norwegian prawn, Nephrops norvegicus, were characterised using immunohistochemistry (Lyons-Alcantara et al., 1999) and the localisation of the nuclear protein PCNA within the nuclei of both fish and prawns was also established using this technique (Suzuka et al., 1989; Ortego et al., 1994).

This research concentrates on the evaluation of antigen expression and protein typing in shellfish tissues. It has been suggested that all vertebrate and invertebrate intermediate filament proteins share a common antigenic determinant (Pruss et al., 1981). Homologues of vertebrate type I, II and III intermediate filament proteins were identified in the invertebrate Branchiostoma lanceolata (Karabinos et al., 1998). It is evident that some proteins are highly conserved in evolution due to the cross reaction of antibodies to human antigens with epitopes in shellfish tissues. This study focuses on the immunohistochemical evaluation of structural and functional proteins in shellfish tissues that have not been previously characterised. A wide range of antibodies to fish and human antigens are investigated to determine their cross reactivity with similar proteins present in abalone tissues using

\section{Table 1}

Specifications and controls for antibodies that bind with antigens in human/mammalian species

\begin{tabular}{|c|c|c|c|c|c|}
\hline Antibody* & Source of immunogen & Clone & Optimal dilution & Antigen retrieval & Positive control \\
\hline $\mathrm{CD} \dagger 20$ & Human & L26 & $1: 1200$ & Microwave & Tonsil \\
\hline $\mathrm{CD}+34$ & Human & QBEnd 10 & $1: 50$ & Microwave & Tonsil \\
\hline $\mathrm{CD} \dagger 68$ & Human & KP1 & $1: 50$ & Microwave & Tonsil \\
\hline Chromogranin A & Human & DAK-AE & $1: 500$ & Microwave & Ileum \\
\hline Cytokeratin AE1/3 & Human & $\mathrm{AE} 1 / 3$ & $1: 800$ & Protease & Pancreas \\
\hline Cytokeratin 8 & Human & 4.1 .18 & $1: 50$ & Microwave and protease & Pancreas \\
\hline Ki67 & Human & MIB-1 & $1: 25$ & Microwave & Tonsil \\
\hline Cytokeratin MNF & Human & MNF 116 & $1: 120$ & Protease & Ileum \\
\hline Collagen IV & Human & CIV22 & $1: 450$ & Microwave & Kidney \\
\hline Human Desmin & Human & D 33 & $1: 50$ & Microwave & Intestine \\
\hline $34 \beta E 12$ & Human & $34 \beta E 12$ & $1: 20$ & Protease & Pancreas \\
\hline LP 34 & Human & LP34 & $1: 50$ & Protease & Skin \\
\hline Muscle Specific Actin (MSA) & Human & HHF 35 & $1: 100$ & Microwave & Pancreas \\
\hline Neurofilament & Porcine & $2 \mathrm{~F} 11$ & $1: 50$ & Microwave & Cerebellum \\
\hline Neuron Specific Enolase-(NSE) & Human & $\mathrm{BB} / \mathrm{NC} / \mathrm{VI}-\mathrm{H} 14$ & $1: 600$ & Microwave & Intestine \\
\hline S100 & Bovine & S100 & $1: 400$ & Microwave & Skin/Sal gland \\
\hline Synaptohysin & Bovine & SY38 & $1: 20$ & Microwave & Pancreas \\
\hline Vimentin & Bovine & VIM 3B4 & $1: 50$ & Microwave & Tonsil \\
\hline Von Willebrand Factor & Human & $\mathrm{F} 8 / 86$ & $1: 75$ & Microwave & Tonsil \\
\hline
\end{tabular}

*All antibodies used were supplied by DakoCytomation ${ }^{\mathrm{TM}}$, Galway, Ireland.

$\dagger \mathrm{CD}$ - Cluster of Differentiation. 
Table 2

Specifications and controls for antibodies that bind with antigens in both vertebrate and invertebrate species

\begin{tabular}{lllllll}
\hline Antibody & Source of immunogen & Clone & Supplier & Optimal dilution & Antigen retrieval & Positive control \\
\hline Cytokeratin AE1 & Human & AE1 & Serotec & $1: 100$ & Protease & Pancreas \\
PCNA & Rat & PC10 & Serotec & Neat & Microwave & Tonsil \\
Vimentin & Porcine & V9 & Serotec & $1: 80$ & Microwave & Smooth muscle \\
Neurofilament & Rat & RmdO-20 & Zymed & $1: 50$ & Microwave & Cerebellum \\
Laminin & Mouse & Polyclonal & Abcam & $1: 100$ & Protease & Liver \\
\hline
\end{tabular}

immunohistochemistry. Where positive immunohistochemical results are observed, western blot analysis is employed to confirm the presence of these specific proteins in abalone tissues.

\section{Materials and methods}

\subsection{Specimen collection and processing}

H. tuberculata and H. discus hannai specimens were obtained from the Boet Mór shellfish farm in Clifden, Co. Galway, Ireland. The animals ranged from one to three years old.

Animals were anaesthetised in a solution of alcohol and seawater (1:1) for $30 \mathrm{~min}$ and transferred to $100 \%$ absolute alcohol for $30 \mathrm{~min}$. The shells were removed and the animals were placed in Davidson's fixative for $24 \mathrm{~h}$. An incision was made lengthwise down the foot muscle of each mollusc to allow penetration of the fixative.

Individual organs were dissected from shellfish $5 \mathrm{~cm}$ in length and animals less than $2 \mathrm{~cm}$ in length were cross-sectioned longitudinally.

\subsection{Paraffin sections}

All animals were processed through the following solutions: $10 \%$ formalin, spirit $(95 \% \mathrm{ETOH})$, absolute alcohol $(\times 5)$, xylene $(\times 3)$ and paraffin wax $(\times 2)$. Tissues were embedded in paraffin wax and $5 \mu \mathrm{m}$ sections were cut using a microtome. Sections were set onto adhesive APES (3-aminopropyltriethoxysilane) coated slides and incubated at $56{ }^{\circ} \mathrm{C}$ for $2-3 \mathrm{~h}$. The following antigen retrieval methods were used on some tissues to enhance immunostaining: (a). microwaving: dewaxed and rehydrated tissue sections were placed in $500 \mathrm{ml}$ citrate buffer ( $2.1 \mathrm{~g}$ citric acid in 11 of distilled water at $\mathrm{pH} 6$ using $2 \mathrm{M}$ $\mathrm{NaOH})$ microwaved $(800 \mathrm{~W})$ for $18 \mathrm{~min}$ and incubated in buffer for a further $20 \mathrm{~min}$ and (b). proteolytic digestion: dewaxed and rehydrated tissue sections were incubated in $0.1 \%$ protease (Streptomyces griseus, Type 24, Sigma) in PBS for $10 \mathrm{~min}$ at $37^{\circ} \mathrm{C}$.

\subsection{Immunostaining protocol}

Shellfish and human tissues were stained using the Vectastain ${ }^{\circledR}$ Elite Avidin-Biotin Complex kits. After antigen retrieval the slides were treated with $3 \%$ hydrogen peroxide in methanol for $10 \mathrm{~min}$. Following rinsing in water, sections were incubated in PBS for $5 \mathrm{~min}$. Sections were covered with normal horse serum (1:100 universal kit; 1:67 mouse kit) for $5 \mathrm{~min}$. They were then drained and the primary antibody diluted in PBS was applied to sections for $60 \mathrm{~min}$ (Tables 1 and 2). The slides were rinsed in PBS $(\times 3)$ and incubated in biotinylated secondary antibody (1:25 universal kit; 1:50 mouse kit) for $15 \mathrm{~min}$. Slides were washed in 3 changes of PBS buffer and incubated for $15 \mathrm{~min}$ in avidin-biotin peroxide complex reagent (1:25 with both kits). Sections were rinsed in buffer and the chromogen, diaminobenzidine-peroxide $\left(0.06 \mathrm{mg} \mathrm{ml}^{-1}\right.$ with $0.03 \%$ hydrogen peroxide) was applied for $5 \mathrm{~min}$ to produce a brown reaction product. Slides were counterstained in Mayer's Haematoxylin for $1 \mathrm{~min}$ and dehydrated

Table 3

Specifications and controls for antibodies used in western blotting

\begin{tabular}{lllllll}
\hline Antibody & Source of immunogen & Clone & Supplier & Optimal dilution & Positive cell line control & Molecular weight (kDa) \\
\hline Cytokeratin AE1 & Human & AE1 & Serotec & $1: 100$ & HeLa & $40 ; 48 ; 50 ; 56$ \\
Cytokeratin MNF & Human & MNF 116 & DAKO & $1: 120$ & HeLa & $45-56.5$ \\
PCNA & Rat & PC10 & Serotec & Neat & HeLa & 36 \\
Vimentin & Porcine & V9 & Serotec & $1: 80$ & CHO $^{\text {a }}$ & 57
\end{tabular}

\footnotetext{
${ }^{\mathrm{a}} \mathrm{CHO}$ - Chinese Hamster Ovary cell line.
} 

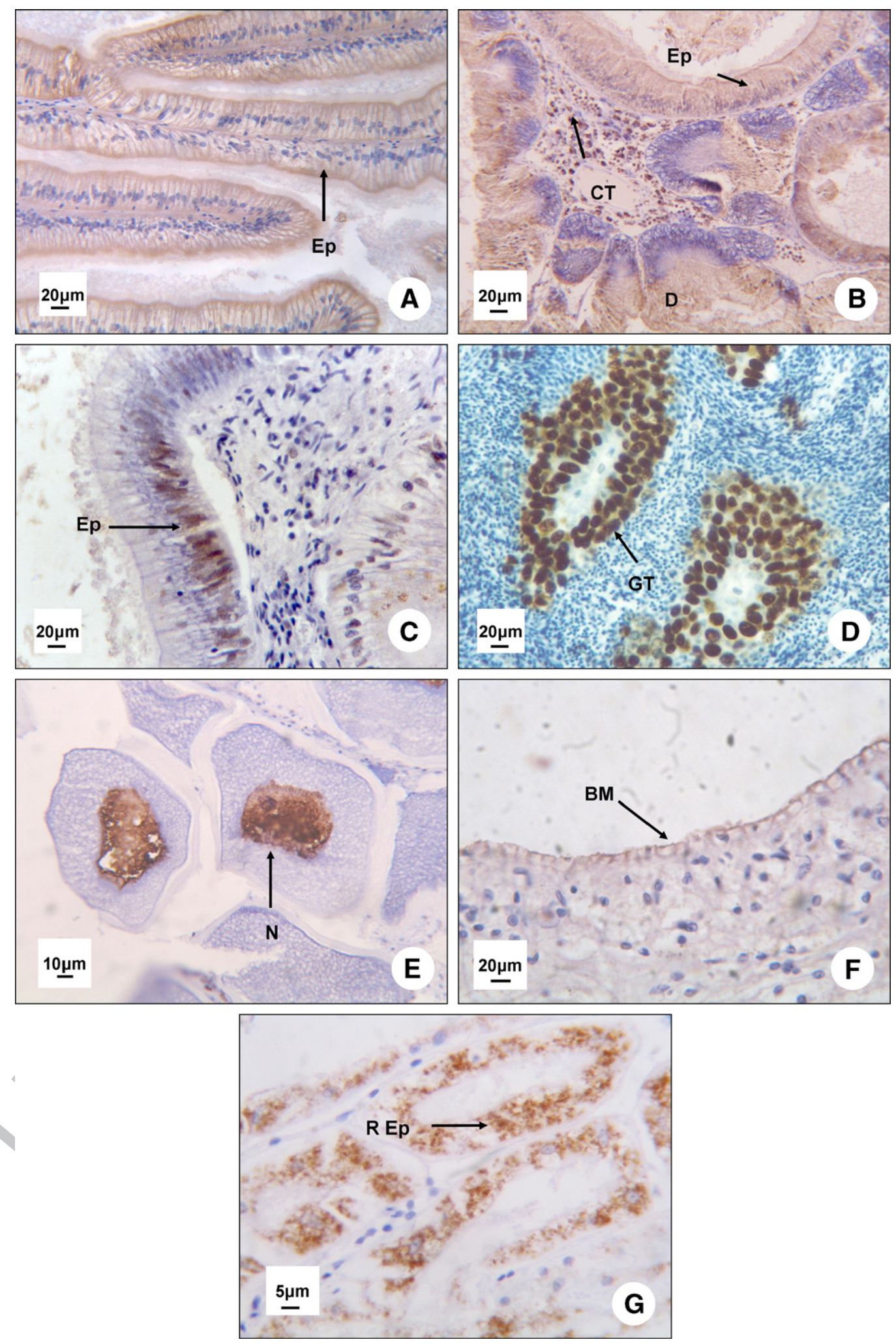
through graded alcohols, cleared in xylene and mounted in Distrene Plasticiser Xylene (DPX). Human tissues were used as positive controls as listed in Tables 1 and 2. Human tissues used as positive controls were supplied by other DIT ethically approved projects. For negative controls, all reagents were applied to abalone tissues except the primary antibody.

\subsection{Protein extraction}

Human cell lines were grown in culture and protein was extracted from fully confluent cells which served as positive controls in western blotting experiments (Table 3). Protein was extracted from cell lines using NP40 Triple detergent lysis buffer $(0.1 \%$ SDS; $150 \mathrm{mM}$ $\mathrm{NaCl} ; 50 \mathrm{mM}$ Tris-Cl (pH 8.0); 1\% Nonidet P-40 (NP40)). $3 \mathrm{ml}$ of NP40 lysis buffer was added to a flask of confluent cells. The lysis buffer containing the cells was centrifuged at $13,000 \mathrm{rpm}$ for $20 \mathrm{~min}$ at $4{ }^{\circ} \mathrm{C}$ and the supernatant was stored at $-20^{\circ} \mathrm{C}$. For protein extraction from abalone tissues, approximately $200 \mathrm{mg}$ of fresh frozen tissue was macerated and suspended in $2 \mathrm{ml}$ SDS lysis buffer (2\% SDS; $50 \mathrm{mM}$ Tris- $\mathrm{HCl}$ (pH 7.2); $1 \mathrm{mM}$ $\beta$-mercaptoethanol) and boiled for $3 \mathrm{~min}$ (Cummins and Hanna, 2004). The sample was homogenised and boiled for $5 \mathrm{~min}$. Samples were centrifuged at 13,000 rpm for $10 \mathrm{~min}$ and the supernatant was collected for storage at $-20{ }^{\circ} \mathrm{C}$. Soluble protein concentrations $(\mu \mathrm{g} / \mathrm{ml})$ of human cell line extracts and abalone tissue extracts were analysed using the Bradford protein assay.

\subsection{Western blot analysis}

For western blot analysis proteins separated by SDSPAGE analysis were transferred to a PVDF (polyvinylidene difluoride) membrane using a semi-dry western blotter (Apollo ${ }^{\mathrm{TM}}$ Instrumentation). The blotter was run at $2 \mathrm{~mA}$ per $\mathrm{cm}^{2}$ of gel for $2 \mathrm{~h}$ after which the membrane was removed and washed briefly with TBS (Tris Buffered Saline) buffer. The membrane was incubated in 5\% BSA blocking solution overnight at $4{ }^{\circ} \mathrm{C}$ on a shaker at a low setting. After blocking the membrane was washed briefly in TBS and the primary antibody was added to the membrane at the appropriate dilution in 5\% BSA blocking solution (Table 3). The membrane was incubated in primary antibody at room temperature for $2 \mathrm{~h}$ on a shaker. The membrane was washed in 5\% BSA blocking solution $(\times 3)$ for $15 \mathrm{~min}$. The biotinylated secondary antibody (diluted in 5\% BSA blocking solution) was added and the membrane was incubated for $1 \mathrm{~h}$ at RT. The membrane was washed in $5 \%$ BSA blocking solution $(\times 3)$ for 15 min. The $\mathrm{ABC}$ reagent (diluted in 5\% BSA blocking solution) was added and the membrane was incubated for $1 \mathrm{~h}$ at RT. The membrane was washed in 5\% BSA blocking solution $(\times 3)$ for $15 \mathrm{~min}$. The membrane was finally incubated in DAB $\left(0.06 \mathrm{mg} \mathrm{ml}^{-1}\right.$ in PBS with $0.03 \%$ hydrogen peroxide) to produce a brown reaction product for the protein of interest. The membrane was washed in 5\% BSA blocking solution and allowed to air dry prior to storage in the dark.

\section{Results}

3.1. Application of antibodies that bind with human/ mammalian antigens to abalone tissues

Twenty antibodies that bind to mammalian antigens were applied to abalone tissues (Table 1). Cross sections of whole animals were used in preliminary trials and any positive staining was subsequently verified by staining individual shellfish organs. Two out of the bodies tested reacted with antigens in abalone tissues: cytokeratin MNF 116 and NSE (Neuron Specific Enolase) (Fig. 1A and B). All human positive control tissues were positive for each antibody tested and negative controls were negative (Table 1). A brown reaction product indicates a positive reaction.

Cytokeratin MNF expression was concentrated in the epithelial cells of the intestine of abalone. The surfaces of the epithelial cells were labelled for this antibody (Fig. 1A). Other epithelial cells of the digestive tract also stained positively for MNF but a more intense intestinal epithelial expression was observed.

NSE produced a pattern of positive staining in the epithelia of the digestive system. This antibody is directed against a neural protein. Antigens within the epithelial cells of the digestive tract and in the duct cells of the hepatopancreas stained positively with this antibody. NSE positive cells were also observed within the connective tissue of the digestive tract (Fig. 1B).

Fig. 1. A. Epithelial cells (Ep) of the intestine of Haliotis discus hannai positive for cytokeratin MNF (brown). B. Duct cells (D), epithelial cells (Ep) and connective tissue (CT) of the digestive gland of Haliotis discus hannai positive for NSE (brown). C. Epithelial cells (Ep) of the intestine of Haliotis discus hannai positive for cytokeratin AE1 (brown). D. Nuclei in the male gonadal tubules (GT) of Haliotis discus hannai positive for PCNA (brown). E. Nuclei (N) of the female eggs of Haliotis discus hannai positive for PCNA (brown). F. Basement membrane (BM) of the foot of Haliotis discus hannai positive for laminin (brown). G. Right renal epithelial cells (REp) of Haliotis tuberculata positive for vimentin (brown). 
245 3.2. Application of antibodies that bind with other

246 vertebrate/invertebrate antigens to abalone tissues

247 Five antibodies that bind to both vertebrate and 248 invertebrate antigens were tested on cross sections of 249 abalone tissues (Table 2). A positive result was then 250 verified by staining sections from individual organs 251 such as the digestive gland, epipodium, foot, gonad and 252 kidney. All human positive control tissues were positive 253 for each antibody tested and negative controls were 254 uniformly negative (Table 2). Cytokeratin AE1 was 255 expressed in some epithelial cells of the digestive 256 system of abalone tissues but not in all epithelial cells.
The positive reaction observed was not uniform rather scattered throughout the cells of the intestine (Fig. 1C). This cytokeratin was also expressed in the pedal epithelia of some abalone.

In abalone tissues both the male and female gonads expressed PCNA. PCNA positive cells were concentrated in the gonadal tubules of the reproductive organs of the male abalone. The cells of the gonad were strongly positive for the presence of this protein (Fig. 1D). Epithelial cells of the digestive system were also positive when stained with this antibody. The nuclei of large but immature ova in the female gonad were also PCNA positive (Fig. 1E).
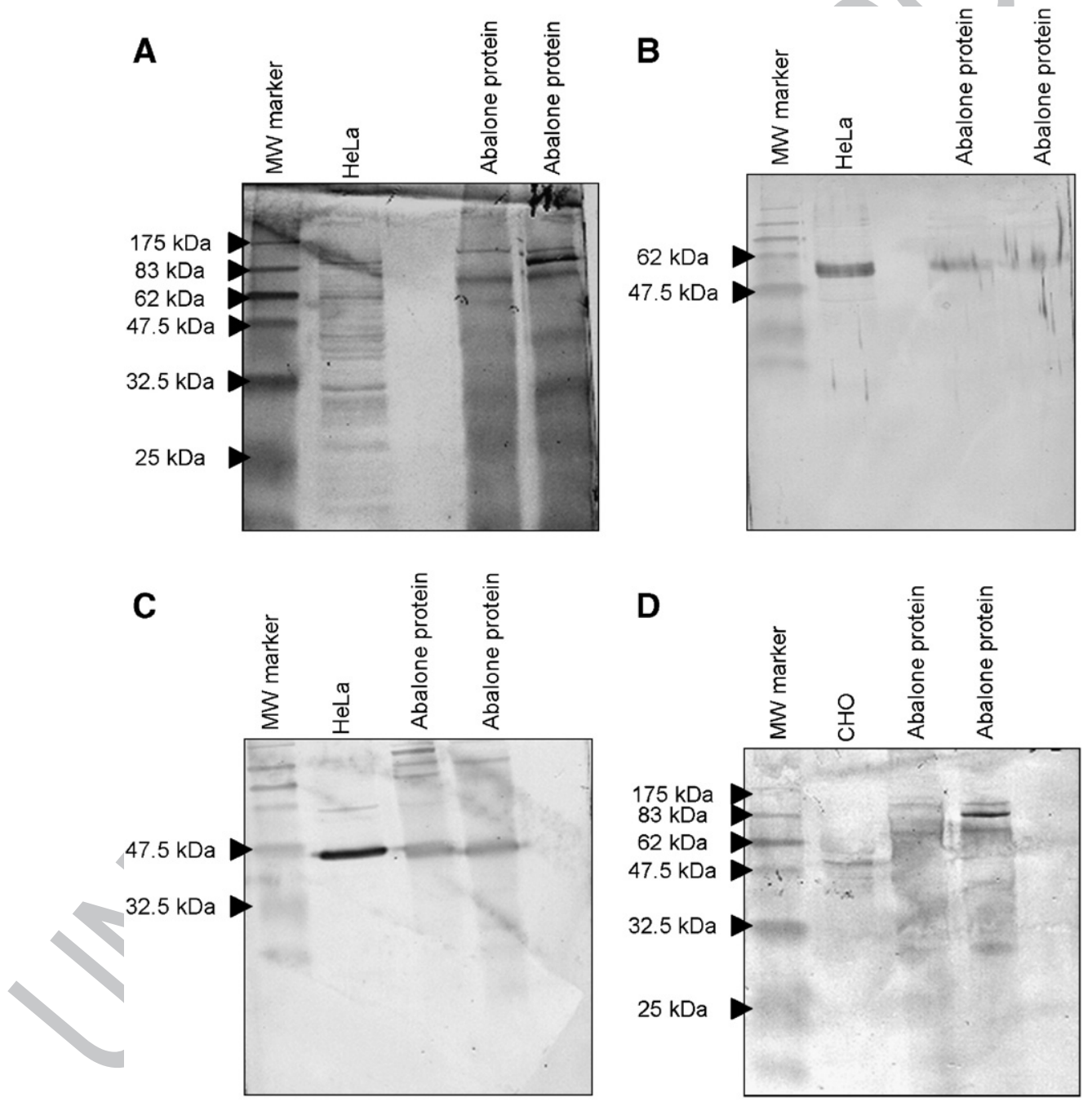

Fig. 2. A. Western blot of HeLa cells $(11.3 \mu \mathrm{g})$ and abalone (H. discus hannai and H. tuberculata) tissue extracts $(6.3 \mu \mathrm{g} ; 7 \mu \mathrm{g})$ using cytokeratin MNF 116 (DAKO). B. Western blot of HeLa cells $(11.3 \mu \mathrm{g})$ and abalone (H. discus hannai and H. tuberculata) tissue extracts $(6.3 \mu \mathrm{g} ; 7 \mu \mathrm{g})$ using cytokeratin AE1 (Serotec). C. Western blot analysis of HeLa cells $(11.3 \mu \mathrm{g})$ and abalone (H. discus hannai and H. tuberculata) tissue extracts $(6.3 \mu \mathrm{g}$; $7 \mu \mathrm{g})$ using PCNA (Serotec). D. Western blot of CHO cells $(8.1 \mu \mathrm{g})$ and abalone (H. discus hannai and H. tuberculata) tissue extracts $(6.3 \mu \mathrm{g} ; 7 \mu \mathrm{g})$ using vimentin V9 (Serotec). 
The antibody laminin was expressed in the basement membrane below the pedal epithelial layer of the abalone foot (Fig. 1F).

Another clone of vimentin was used in this section of the study. A granular staining pattern was expressed in the cytoplasm of the right renal organ of abalone using this antibody (Fig. 1G).

\subsection{Western blotting results}

Proteins identified in abalone tissues by immunohistochemistry were further investigated and identified by $\mathrm{ABC} / \mathrm{DAB}$ detection in western blotting using SDSPAGE and transfer to PVDF membranes. Western blot analysis confirmed the presence of cytokeratin MNF, cytokeratin AE1, PCNA and vimentin in abalone tissues.

Western blot analysis confirmed the presence of cytokeratins in abalone using MNF and AE1 antibodies. The broad spectrum antibody cytokeratin MNF which detects a wide range of proteins, revealed proteins with molecular weights of between 25 and $175 \mathrm{kDa}$ in the HeLa positive control (Fig. 2A). With abalone samples, 3 strong bands with molecular weights of 100, 83 and $70 \mathrm{kDa}$ approximately were identified and weaker bands were observed in the $32.5-47.5 \mathrm{kDa}$ range (Fig. 2A). A very strong band at $83 \mathrm{kDa}$ in the second sample can be observed in Fig. 2A. The lower molecular weight bands correspond to keratins 5, 6, 8, 17 and 19 while the high molecular weight proteins identified do not correspond to known cytokeratins.

The antibody cytokeratin AE1 identifies proteins with molecular weights of $40-56.5 \mathrm{kDa}$. A single band with a molecular weight of $56.5 \mathrm{kDa}$ approximately was identified in both the positive HeLa control cells and abalone samples, which corresponds to cytokeratin 10 (Fig. 2B).

Western blot analysis with PCNA identified clear bands with a molecular weight of approximately $36 \mathrm{kDa}$ in the HeLa positive control and whole protein extracted from abalone tissues (Fig. 2C). In Fig. 2C specific bands between 83 and $175 \mathrm{kDa}$ can be observed despite a lower concentration of protein than the positive control.

Stronger bands observed with HeLa positive controls compared with abalone protein in western blots with antibodies AE1 and PCNA, could be indicative of higher concentrations of extracted protein.

Protein bands were detected in abalone tissues with the vimentin antibody using western blotting (Fig. 2D). A band was observed in the $\mathrm{CHO}$ positive control which corresponds to the $57 \mathrm{kDa}$ band expected with vimentin.
A very strong band and two weaker bands were identified with molecular weights of between 83 and $175 \mathrm{kDa}$ in the second abalone sample while the stronger band was not observed in the first sample. The strong band observed in Fig. 2D is very specific despite lower concentrations of abalone compared to the $\mathrm{HeL}_{\mathrm{n}}$ positive control.

\section{Discussion}

Immunohistochemistry is a highly valued technique that allows for the study of functional and structural entities within tissues. It allows for the analysis of protein distribution within tissues and has the potential for application in marine research. However, the lack of specific antibodies to shellfish antigens remains a major limitation.

Previous studies have used immunohistochemistry to study the hemocytes/immune cells of molluscs (Yoshino and Granath, 1983; Ottaviani, 1989; Noël et al., 1994; Xue and Renault, 2001). These studies focused on the definition of molluscan hemocyte type and the determination of hemocyte distribution within tissues using antibodies produced specifically to detect these cells. Few if any shellfish studies are available that have aimed to characterise cells other than immune cells.

This study demonstrated cytokeratin expression in abalone tissues using broad spectrum antibodies MNF 116 and cytokeratin AE1. Keratins are intermediate filaments of epithelial cells and they have a structural role in tissues. The paper of Diogo et al. (1994) was the first study to characterise invertebrate cytokeratins. Since then cytokeratins have been characterised in the prawn and shrimp (Lyons-Alcantara et al., 1999, 2002). Cytokeratin MNF recognises proteins of molecular weight $45-56.5 \mathrm{kD}$ and cytokeratin AE1 recognises proteins with a molecular weight of $56.5,50,48$ and $40 \mathrm{kD}$. The epitopes that are thus being targeted by these two antibodies are in the same molecular weight range. Both antibodies react positively to normal human epithelia and their neoplasms showing a broad range of reactivity (Leong et al., 2002). Four cytokeratins were tested, and two were expressed in abalone tissues. Cytokeratin AE1 reacted positively with cytoplasmic proteins in the intestinal epithelia of abalone and cytokeratin MNF was present on the surface of the intestinal epithelia. These results were reinforced by western blot analysis and while AE1 produced a specific band of $56.5 \mathrm{kDa}$ in abalone samples, western blotting with cytokeratin MNF revealed many protein bands in abalone tissues indicating numerous cytokeratins, some of which were very distinct. 
PCNA is a multifunctional cell marker representing a

371 component of DNA polymerase- $\delta$. It is a proliferating

372 cell marker producing a staining pattern that is generally

373 confined to the nuclei of actively proliferating tissues

374 and cells. This cell marker has been detected in

375 mammals, prawns, fish and some higher plants (Suzuka

376 et al., 1989; Ortego et al., 1994; Lyons-Alcantara et al.,

377 1999). In this study PCNA was detected in abalone

378 tissues. Antigens in the nuclei of the reproductive organs

379 of both male and female abalone reacted positively with

380 this antibody. Cells of the gonad are constantly

381 undergoing proliferation giving rise to new cells thus

382 explaining the presence of PCNA in these areas. Not all

383 abalone proliferating cells expressed this antigen,

384 mainly epithelial proliferating cells. PCNA positivity

385 was also located in the nuclei of epithelial cells of the

386 hepatopancreas, however the degree of positivity within

387 epithelial tissues was scattered. Western blot analysis

388 also confirmed the presence of PCNA in abalone tissues

389 and additional molecular weight bands, higher than the

39036 kDa specific band were observed.

391 Vimentin, a protein expressed in virtually all 392 mesenchymal cells was also present in abalone tissues.

393 Vimentin has been shown to produce a cytoplasmic

394 pattern of staining in the invertebrate Drosophila

395 melanogaster (Walter and Biessmann, 1984) and has

396 been recognised as a cytoskeletal constituent of many

397 fish tissues (Nelson and Traub, 1982; Gyoeva et al.,

398 1987) and in invertebrate tissues (Karabinos et al.,

399 1998). Markl et al. (1989) used gel electrophoresis,

400 immunostaining and immunoblot assays to identify

401 vimentin in rainbow trout tissues. They concluded that

402 the identified cytoskeletal protein is homologous to

403 mammalian vimentin but it only makes up a very small

404 component of the cytoskeleton. In this study the V9

405 clone $(57 \mathrm{kDa})$ detected vimentin in the kidney of

406 abalone and a granular cytoplasmic staining pattern was

407 observed which was confirmed by western blotting with

408 bands in the $57 \mathrm{kDa}$ range but more definite bands were

409 observed at $83 \mathrm{kDa}$.

410 Three different antibodies were employed to detect

411 elements of the nervous system of abalone, NSE,

412 neurofilament and S100. Neurofilament and S100

413 were not detected while NSE, an isoenzyme of enolase

414 present in neurons and neuroendocrine cells (Leong et

415 al., 2002) was demonstrated in the epithelial cells of the

416 digestive gland and in the connective tissue of the

417 digestive tract. The prosobranch body is entirely

418 innervated and NSE could be cross-reacting with an

419 enolase enzyme released by the intestinal ganglia.

420 Western blot analysis did not confirm the presence of

421 NSE in abalone tissues. Nerve cells have recently been characterised in $H$. asinina Linnaeus using antibodies to serotonin and FMRF-amide neurotransmitters (Panasophonkul et al., 2004).

Another antibody that cross-reacted with antigens in abalone tissues was laminin. Its presence indicates the highly conserved nature of this structural protein, being present in many species from invertebrates to vertebrates (Sarras et al., 1994; Zhang et al., 1994; Yurchenco and Waddsworth, 2004). Laminin is an embryonically expressed protein that is essential for basement membrane assembly and is one of the most ancient proteins within extracellular matrices (Cooper and McQueen, 1983; McCarthy et al., 1987; Montell and Goodman, 1989; Yurchenco and Waddsworth, 2004). Previous studies on invertebrate laminins have employed immunofluorescent and immunohistochemical techniques to identify these proteins (Sarras et al., 1993, 1994). Laminin was observed in the basement membrane of the abalone foot. Western blot analysis was not performed with laminin since only a small number of basement membranes expressed this protein with immunostaining.

The use of mammalian and veterinary antibodies in this study gives an indication of the structural, functional and proliferative framework that makes up the tissues of abalone, which will be helpful in studying the effects of pathogens on this shellfish through comparisons of both healthy and diseased organisms. The key findings of this study are that PCNA, cytokeratins, NSE and vimentin are important biomarkers of proliferation and differentiation in abalone species. Immunohistochemistry acts as a helpful adjunct to histology, histochemistry and other studies of cellular function. However further progress in this area is dependent upon antibodies specific to shellfish antigens being developed.

\section{Acknowledgement}

This work was supported by the Dublin Institute of Technology, Strand 1 scheme of the Technological Research Programme, which is funded by The National Development Plan (02/RDS/S55)

\section{References}

Avrameas, S., Uriel, J., 1966. Methode de marquage d'antigènes et d'anticorps avec des enzymes et son application en immuno diffusion. C. R. Acad. Sci. 262, 2543-2545.

Bacetti, B., Burrini, A.G., Gabbiani, G., Leoncini, P., RunggerBrandle, E., 1984. Filamentous structures containing a keratin-like protein in spermatozoa of an insect, Bacillus rossius. J. Ultrastruct. Res. 86, 86-92.
458 
Nelson, W.J., Traub, P., 1982. Intermediate $(10 \mathrm{~nm})$ filament proteins and $\mathrm{Ca}^{2+}$-activated proteinase specific for vimentin and desmin in the cells from fish to man: an example of evolutionary conservation. J. Cell Sci. 57, 25-49.

Noël, D., Pipe, R., Elston, R., Bachère, E., Mialhe, E., 1994. Antigenic characterization of hemocyte subpopulations in the mussel Mytilus edulis by means of monoclonal antibodies. Mar. Biol. 119, 549-556.

Ortego, L.S., Hawkins, W.E., Walker, W.W., Krol, R.M., Benson, W.H., 1994. Detection of proliferating cell nuclear antigen in tissues of three small fish species. Biotech. Histochem. 69, 317-323.

Ottaviani, E., 1989. Haemocytes of the freshwater snail Viviparus ater (Gastropoda, Prosobranchia). J. Molluscan Stud. 55, 379-382.

Panasophonkul, S., Sretarugsa, P., Anunruang, N., Apisawetakanm, S., Saitongdee, P., Upathum, A., Poomtong, T., Hanna, P.J., Sobhon, P., 2004. Serotonergic and FMRF-amidergic neurons in the nerve ganglia of Haliotis asinina Linnaeus. J. Shellfish Res. 23, 1087-1095.

Pruss, R.M., Mirsky, R., RaffRobin Thorpe, M.C., Dowding, A.J., Anderton, B.H., 1981. All classes of intermediate filaments share a common antigenic determinant defined by a monoclonal antibody. Cell 27, 419-428.

Roch, P., 1999. Defense mechanisms and disease prevention in farmed marine invertebrates. Aquaculture 172, 125-145.

Sarras Jr., M.P., Zhang, X., Huff, J.K., Accavitti, M.A., St. John, P.L., Abrahamson, D.R., 1993. Extracellular matrix (mesoglea) of $\mathrm{Hy}$ dra vulgaris. III. Formation and function during morphogenesis of hydra cell aggregates. Dev. Biol. 157, 383-398.

Sarras Jr., M.P., Yan, L., Grens, A., Zhang, X., Agbas, A., Huff, J.K., St. John, P.L., Abrahamson, D.R., 1994. Cloning and biological function of laminin in Hydra vulgaris. Dev. Biol. 164, 312-324.

Suzuka, I., Daidoji, H., Matsuoka, M., Kadowaki, K., Takasaki, Y., Nakane, P.K., Moriuchi, T., 1989. Gene for proliferating cell nuclear antigen (DNA polymerase auxiliary protein) is present in both mammalian and higher plant genomes. Proc. Natl. Acad. Sci. 86, 3189-3193

Voltzow, J., 1994. Gastropoda: Prosobranchia. In: Harrison, F.W., Kohn, A.J. (Eds.), Microscopic Anatomy of Invertebrates. Volume 5: Mollusca 1. Wiley-Liss, Inc., New York, pp. 111-252.

Vullings, H.G.B., Legerstee-Oostveen, G.G., Diedreen, J.H.B., Jansen, W.F., 1989. Immunocytochemical demonstration of neuronspecific enolase in neuronal cell bodies of an insect. Neurosci. Lett. 104, 48-52.

Walter, M.F., Biessmann, H., 1984. A monoclonal antibody that detects vimentin-related proteins in invertebrates. Mol. Cell. Biochem. 60, 99-108.

Xue, Q., Renault, T., 2001. Monoclonal antibodies to European flat oyster Ostrea edulis hemocytes: characterization and tissue distribution of granulocytes in adult and developing animals. Dev. Comp. Immunol. 25, 187-194.

Yoshino, T.P., Granath Jr., W.O., 1983. Identification of antigenically distinct hemocyte subpopulations in Biomphalaria glabrata (Gastropoda) using monoclonal antibodies to surface membrane markers. Cell Tissue Res. 232, 553-564.

Yurchenco, P.D., Waddsworth, W.G., 2004. Assembly and tissue functions of early embryonic laminins and netrins. Curr. Opin. Cell Biol. 16, 572-579.

Zhang, X., Hudson, B.G., Sarras Jr., M.P., 1994. Hydra cell aggregate development is blocked by selective fragments of fibronectin and type IV collagen. Dev. Biol. 164, 10-23. 14, 929-931. 